acidity could reduce magnesium uptake by lowering the magnesium/aluminium ratio in soil solution.

Unlike Hauhs and Ulrich, we believe that aluminium toxicity is unlikely to occur at most sites. It is now known that the Solling is an exceptional area regarding aluminium availability ${ }^{4}$. Part of the increase in magnesium deficiency between 1976 and 1988 was due to the drought years of 1975-76 and 1981-84. In dry years there may be less magnesium released from litter, less magnesium uptake from subsoil, poorer root development and more leaching due to nitrification. Ozone may be involved in reducing root growth in dry years, but the effect on foliar leaching is small. In wetter years, litter mineralization and soil weathering should supply more magnesium and the symptoms will be reduced. This explains the reversibility of type 1 decline in West Germany since 1985.

An important factor in magnesium depletion in sensitive areas is deposition of sulphur and nitrogen. However, Hauhs and Ulrich fail to acknowledge that tree harvesting is an equally important mechanism of removing magnesium, as demonstrated in element budget studies of the type advocated by Hauhs ${ }^{3}$. The obvious immediate remedial action from our analysis of the problem should be based on the addition of magnesium to soils. Adding lime or limestone, as suggested by Ulrich ${ }^{5}$, will not be effective in correcting the symptoms of magnesium deficiency.

In a European context, it is relevant that magnesium deficiency has not been apparent in the forests of countries along the maritime seaboard of northern Europe (the reason is that the rate of magnesium deposition in precipitation is much greater there than in central Europe). Consequently, the symptoms of magnesium deficiency have not been seen in Britain or Norway, even in areas of high acid deposition, nor do coniferous forests in these regions respond to fertilization with magnesium.

Research on other types of forest damage has not advanced as far as that on type 1 spruce decline. The practical implications of understanding these scientific issues are profound. Soil acidification can be reversed by liming; nutrient limitations require re-addition of the limiting nutrients; direct effects of pollution require reduction of the pollutants in question; pathogen infections require symptomatic treatment. But if the causes

1. Ulich, B. \& Pankrath, J. Effects of Accumulation of Air Pollutants in Forest Ecosystems (Reidel, Dordrecht. 1983),

2. Forschungsbeirat Waldschäden/Luftverunreinigungen (Report 2, Karisruhe, 1986).

3. Roberts, T.M., Skeffington, R.A. \& Blank, L.W. Forestry 62 $179-222$ (in the press)

4. Cronan, L.S. in Acid Rain: Scientific and Technical Advances (Perry, R., Harrison, R.M. \& Bell, J.N.B. eds) 644-656 (Selper, London, 1987).

5. Ulrich, B. Forstw. Cbl. 105, 421-434 (1986). are not properly identified then resources will be wasted in ineffective treatments.

L.W. BLANK

R.A. SKEFFINGTON

Central Electricity Research Laboratories,

Kelvin Avenue, Leatherhead,

Surrey KT22 7SE, UK

Institute of Terrestrial Ecology,

Monks Wood Experimental Station,

Huntingdon PE17 2LS, UK

\section{Baikal seal virus}

SIR-We have recently reported ${ }^{1,2}$ evidence that the cause of the disease in Lake Baikal seals (Phoca siberica) in the autumn of studied for comparison.

Gold particles in livers of both seal and dog were present mainly as clusters, which were particularly abundant in cell nuclei ( $a, b$ in the figure). Some clusters reside on virus-like particles of oval or hexagonal form having a diameter of about $80 \mathrm{~nm}$. ( $c, d$ in the figure). Similar patterns were seen in kidneys, but in spleens gold spheres were present as single particles rather than clusters. The proportion of cells containing morbillivirus antigens was high, indicating the severity of infection. Practically no gold particles were found in controls treated with gold-protein $\mathrm{A}$ in the absence of monoclonal antibodies.

The similarity of the patterns obtained
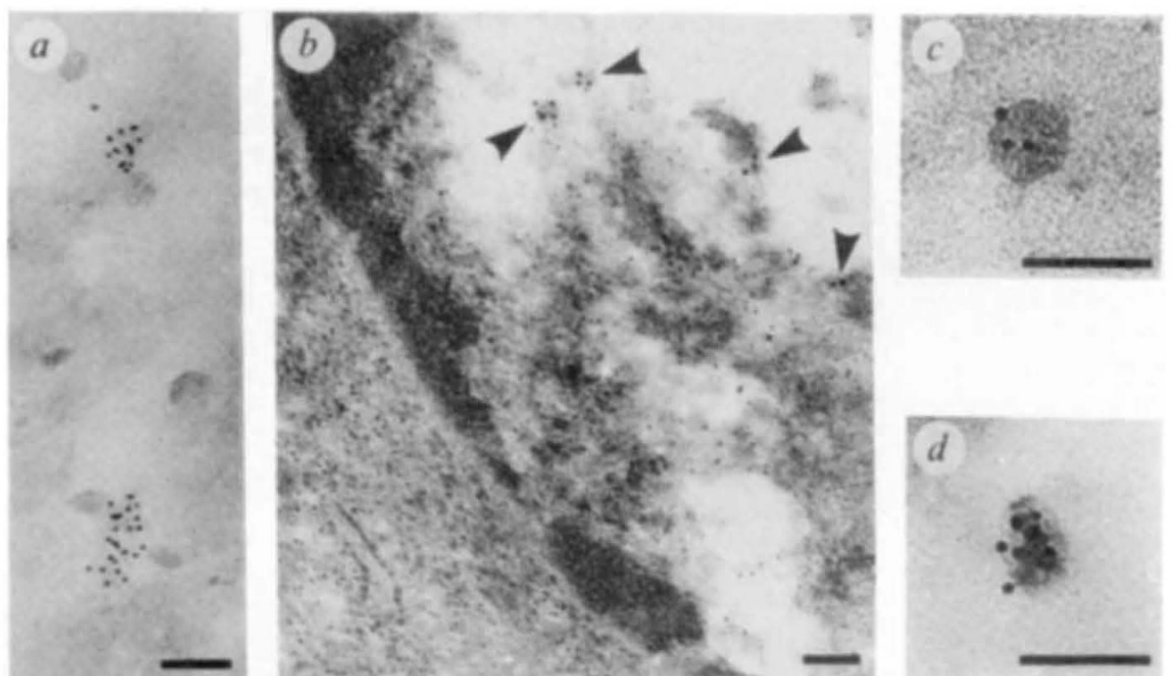

Immunoelectron microscopy of dog liver $(a, c)$ and seal liver $(b, d)$. Scale bar, $100 \mathrm{~nm}$. Tissues were fixed in $4 \% \mathrm{CHO} / 0.4 \%$ glutaric aldehyde phosphate for $2 \mathrm{~h}$, kept in $2.1 \mathrm{M}$ sucrose for $1 \mathrm{~h}$. Sections $(15-20 \mu \mathrm{m})$ were cut at $-10^{\circ} \mathrm{C}$ into $10 \mathrm{mM}$ Tris- $\mathrm{HCl}(\mathrm{pH} 8), 0.15 \mathrm{M} \mathrm{NaCl}, 0.05 \%$ Tween-20,0.1\% ovalbumin. Monoclonal antibodies BK-228 (raised in mice against human measles virus strain Leningrad-16) and LEC-27 (raised against measles virus from a patient with sclerosing panencephalitis) were applied at concentrations 0.135 or $1.35 \mu \mathrm{g} / \mathrm{ml}$ (BK-228), and 0.16 or $1.6 \mu \mathrm{g} \mathrm{ml}-1$ (LEC-27). Incubation overnight at $4{ }^{\circ} \mathrm{C}$ was followed by addition of colloid gold-protein A (Bios, Novosibirsk; $15 \mathrm{~nm}$ particles). After $1 \mathrm{~h}$, sections were dehydrated and embedded in Epon-Araldite. Ultra-thin sections were cut, contrasted with uranyl acetate, and examined with a Philips EM-410 electron microscope at $60 \mathrm{kV}$.

1987 was infection by a morbillivirus similar to canine distemper virus (CDV). The same, or a very similar, virus attacked European seals the following spring ${ }^{3-7}$. By means of electron microscopy combined with immunogold staining, we can now confirm the presence of morbillivirus antigens in the tissues of a seal.

The seal, kept in captivity, died with typical symptoms of distemper. Its serum contained anti/CDV antibodies, and its spleen and liver gave a positive reaction with oligonucleotide probes ${ }^{1}$. Pieces of liver, kidney and spleen were fixed, sectioned, exposed first to monoclonal antibodies against the morbillivirus that causes measles, then to colloidal gold-protein A. Tissues of a dog infected with CDV were

1. Grachev, M.A. et al. Nature 338, 209 (1989).

2. Osterhaus, A.D.M.E. et al. Nature 338, 209-210 (1989).

3. Osterhaus, A.D.M.E. \& Vedder, E.J. Nature 335, 20 (1988).

Osterhaus, A.D.M. E et al Nature 335, 403-404 (1988)

5. Kennedy, S. et al. Nature 335, 404 (1988).

6. Mahy, B.W.J. et al. Nature 336, 115 (1988)

7. Cosby, S.L. et al. Nature 336, 115-116 (1988). with seal and dog tissues is in favour of the suggestion that a morbillivirus similar to CDV caused the disease of Baikal seals.

YE. V. LIKHOSHWAY

M. A. GRACHEV*

V.P. KUMAREV

Limnological Institute,

Siberian Division of the USSR Academy of Sciences,

Lermontov 281,

664033 Irkutsk, USSR

YU. V. SOLODUN

O. A. GOLDBERG

O. I. BELYKH

Institute of Surgery,

East Siberian Division Academy of

Medical Sciences,

F. G. NAGIEVA

V. G. NIKULINA

Moscow Research Institute of Viral Preparations

Irkutsk Anti-Plague Institute

B. S. KOLESNIK

*Author to whom correspondence should be addressed. 